\author{
SERIES "CONTRIBUTIONS FROM THE EUROPEAN RESPIRATORY MONOGRAPH" \\ Edited by M. Decramer and A. Rossi \\ Number 6 in this Series
}

Environmental tobacco smoke and health in the elderly

\author{
M.S. Jaakkola
}

\begin{abstract}
Environmental tobacco smoke and health in the elderly. M.S. Jaakkola. (C)ERS Journals Ltd 2002.

ABSTRACT: The aims of this article are to synthesize the evidence on health effects of environmental tobacco smoke (ETS) in the elderly and to discuss questions for future research. Health effects are divided into aetiological and prognostic studies.

There is convincing evidence that ETS causes lung cancer and coronary heart disease, both of which are diseases of the elderly. Several cross-sectional studies show increased occurrence of chronic respiratory symptoms and deficits in ventilatory lung function in relation to ETS exposure at home and/or at work.

A limited number of studies have found significant relations between ETS exposure and asthma, chronic obstructive pulmonary disease (COPD), pneumococcal infections and stroke in the elderly. Longitudinal studies are needed before any definite conclusions can be made concerning ETS and noncarcinogenic respiratory diseases in the elderly.

The potential role of environmental tobacco smoke exposure as a prognostic factor determining development of a pre-existing respiratory or heart disease is an important new area for research.

Eur Respir J 2002; 19: 172-181.
\end{abstract}

Finnish Institute of Occupational Health, Helsinki, Finland.

\author{
Correspondence: M.S. Jaakkola \\ Finnish Institute of \\ Occupational Health \\ Topeliuksenkatu 41 aA \\ FIN-00250 Helsinki \\ Finland \\ Fax: 35894583092
}

Keywords: Asthma

chronic obstructive pulmonary disease elderly

lung cancer

lung function

tobacco smoke pollution

Received: August 102001

Accepted after revision August 102001
Personal smoking is a well-established cause of lung cancer, chronic obstructive pulmonary disease (COPD) and coronary heart disease [1]. The first reports associating spouse's smoking to lung cancer in nonsmoking females were published in 1981 [2, 3]. Since then the research on health effects of environmental tobacco smoke (ETS) has expanded, especially on respiratory effects in children and lung cancer in adults [4].

The aims of this article are to synthesize the evidence on health effects of ETS in the elderly and to discuss questions for future research. The health effects are separated into two categories: aetiological studies, i.e. studies on development of a new disease, and prognostic studies, i.e. studies on development over time (or natural history) of a pre-existing disease. The incidence of many diseases that have been related to ETS exposure, such as COPD and lung cancer, increases with age $[1,5]$. Table 1 summarizes the aetiological studies of ETS in the elderly. It also presents the author's judgement on causality of the relations, based on the amount of studies, their validity, evidence of dose-response relations, and biological plausibility. Surprisingly few studies have evaluated the role of ETS in determining the prognosis of a pre-existing disease, such as asthma or COPD, although this may be of great importance for the elderly in their every day life. In this age period, small changes in respiratory function can have a critical impact on their overall functional capacity. In addition, elderly people with an underlying disease may be exposed to very high levels of ETS, if their disease restricts them to indoor environments.

\section{Environmental tobacco smoke exposure}

Tobacco smoke contains $>4,000$ compounds, including $>50$ human and/or animal carcinogens and many irritant and toxic agents [6, 7]. Mainstream smoke and sidestream smoke are qualitatively very similar, but the quantities of constituents differ due to different burning conditions [6]. Sidestream smoke, emitted directly into the air during burning of a tobacco product between puffs, contains considerably higher concentrations of many carcinogens and toxic substances (table 2), but is diluted into a larger volume of air. Detectable levels of cotinine, a biomarker of ETS exposure in serum, urine and saliva, have been measured in $\geqslant 80 \%$ of the nonsmoking populations [8,9]. In a survey representing a US civilian noninstitutionalized population, the reported ETS exposure at home or at work was $18 \%$ among males and $11 \%$ among females in the age group $\geqslant 60$ yrs [9]. Assessment of exposure to ETS is an essential part when studying health effects, carrying out risk assessment, and developing preventive strategies, as discussed in previous articles [10, 11]. 
Table 1. - Summary of aetiological studies on environmental tobacco smoke and respiratory diseases and conditions in the elderly

\begin{tabular}{|c|c|c|c|}
\hline Disease/condition & $\begin{array}{l}\text { OR or } \\
\text { range } \\
\text { in ORs }\end{array}$ & $95 \% \mathrm{CI}$ & Causality \\
\hline \multicolumn{3}{|l|}{ Lung cancer } & \multirow{3}{*}{+++} \\
\hline Home exposure & 1.23 & $1.13-1.34$ & \\
\hline Work exposure & 1.25 & $1.08-1.41$ & \\
\hline \multicolumn{3}{|l|}{$\begin{array}{l}\text { Chronic respiratory } \\
\text { symptoms }\end{array}$} & \multirow[t]{5}{*}{+} \\
\hline Wheezing & \multicolumn{2}{|l|}{$1.35-2.69$} & \\
\hline Cough & \multicolumn{2}{|l|}{$2.80-3.79$} & \\
\hline Phlegm & \multicolumn{2}{|l|}{$1.60-3.40$} & \\
\hline Dyspnoea & \multicolumn{2}{|l|}{$1.35-4.50$} & \\
\hline Asthma & \multicolumn{2}{|l|}{$1.45-1.97$} & ++ \\
\hline COPD & \multicolumn{2}{|l|}{$1.68-5.63$} & + \\
\hline Respiratory infections & 2.5 & $1.2-5.1$ & + \\
\hline \multicolumn{3}{|l|}{ Coronary heart disease } & \multirow[t]{3}{*}{+++} \\
\hline Home exposure & 1.30 & $1.22-1.38$ & \\
\hline Work exposure & 1.21 & $1.04-1.41$ & \\
\hline Stroke & 1.82 & $1.34-2.49$ & + \\
\hline \multicolumn{4}{|l|}{ Lung function parameter ${ }^{+}$} \\
\hline $\begin{array}{l}\text { Cross-sectional } \\
\text { studies FEV1 }\end{array}$ & $-2.7 \%{ }^{\S}$ & $-4.1 \%-1.2 \%{ }^{\S}$ & + \\
\hline $\begin{array}{l}\text { Longitudinal study } \\
\text { FEV1 }\end{array}$ & NS & & 0 \\
\hline
\end{tabular}

FEV1: forced expiratory volume in one second. ${ }^{\text {\#}}$ : odds ratio (OR) and 95\% confidence interval (CI) from metaanalysis or, if a summary estimate is not available, range of ORS from individual studies (references for each disease and condition are given in the text). ${ }^{\S}$ : data are presented as effect estimate (95\% CI). The difference in FEV1 level between the exposed and unexposed, expressed as a percentage of the level in the unexposed group. ": causality as judged by the author; +++ : causal relation established; ++ : strong evidence of a causal relation; + : some evidence of a causal relation; 0: no clear evidence of a causal relation.

\section{Aetiological studies of environmental tobacco smoke exposure and health in the elderly}

\section{Lung cancer}

The induction period of lung cancer is long, so its risk is likely to be related to the cumulative ETS exposure over entire adulthood, while the diagnosis is often confirmed in the older age. Altogether 38 case-control studies [12-49] and five prospective studies [50-54] from 12 countries have been published on ETS and lung cancer, and several meta-analyses of these have been performed [6, 55-60] (figs. 1a and $1 b)$. In a recent meta-analysis of studies on spousal smoking, the pooled odds ratio (OR) was $1.24(95 \%$ confidence interval (CI) 1.13-1.36) for females and 1.34 (95\% CI 0.97-1.84) for males [58]. The estimated OR for females and males combined was $1.23(95 \%$ CI 1.13-1.34) (table 1). Adjustment for potential misclassification of some active smokers as neversmokers, misclassification of the reference group due to ETS exposure from sources other than the spouse, and confounding by dietary habits did not change these estimates. Several studies have shown a
Table 2.-Emissions of selected tobacco smoke constituents in fresh, undiluted mainstream smoke (MS) and diluted sidestream smoke (SS) from unfiltered cigarettes

\begin{tabular}{lcc}
\hline Constituent & $\begin{array}{c}\text { Emissions } \\
\text { in MS }\end{array}$ & $\begin{array}{c}\text { Range in } \\
\text { SS/MS ratio }\end{array}$ \\
\hline Known human carcinogens & & \\
Benzene & $12-48 \mu \mathrm{g}$ & $5-10$ \\
2-naphthylamine & $1.7 \mathrm{ng}$ & 30 \\
4-aminobiphenyl & $4.6 \mathrm{ng}$ & 31 \\
Polonium-210 & $0.04-0.1 \mathrm{pCi}$ & $1-4$ \\
Nickel & $20-80 \mathrm{ng}$ & $13-30$ \\
Probable human carcinogens & & \\
Formaldehyde & $70-100 \mu \mathrm{g}$ & $0.1-50$ \\
Hydrazine & $32 \mathrm{ng}$ & 3 \\
$N$-nitrosodimethylamine & $10-40 \mathrm{ng}$ & $20-100$ \\
$N$-nitrosodiethylamine & $\mathrm{ND}-25 \mathrm{ng}$ & $<40$ \\
$N$-nitrosopyrrolidine & $6-30 \mathrm{ng}$ & $6-30$ \\
1,3-butadiene & $69.2 \mu \mathrm{g}$ & $3-6$ \\
Aniline & $360 \mathrm{ng}$ & 30 \\
Benzo(a)pyrene & $20-40 \mathrm{ng}$ & $2.5-3.5$ \\
Cadmium & $110 \mathrm{ng}$ & 7.2 \\
Irritant and toxic compounds & & \\
Carbon monoxide & $10-23 \mathrm{mg}$ & $2.5-4.7$ \\
Acrolein & $60-100 \mu \mathrm{g}$ & $8-15$ \\
Acetone & $100-250 \mu \mathrm{g}$ & $2-5$ \\
Ammonia & $50-130 \mu \mathrm{g}$ & $3.7-5.1$ \\
Nitrogen oxides & $100-600 \mu \mathrm{g}$ & $4-10$ \\
\hline
\end{tabular}

\#: pCi: picocurie $\left(1\right.$ curie $=3.7 \times 10^{10}$ Becquerel $)$; ND: nondetectable. (From the report by the US Environmental Protection Agency [6]).

dose-dependent increase in the risk of lung cancer by the number of cigarettes smoked daily by the spouse, by the number of years the subject lived with a smoker, and by cumulative exposure in pack-yrs $[4,58]$.

Workplace is another major source of ETS exposure in adulthood [6, 8, 9]. Altogether 20 studies have assessed the risk of lung cancer in relation to workplace ETS exposure [4, 16, 18, 19, 21, 29, 31-33, $35,37,38,41,42,45-49,52,61,62]$. The studies including quantitative assessment of occupational ETS exposure have usually indicated a relation with the risk of lung cancer, and in general, the risk estimates for workplace ETS exposure have been consistent with the estimates for spousal smoking. In a recent meta-analysis of 14 workplace ETS studies, the pooled OR for lung cancer was 1.25 (95\% CI 1.08-1.41) (table 1) [60].

In conclusion, a causal relation between ETS and lung cancer is supported by a large amount of studies from different geographical locations, genetic populations and cultural environments. ETS contains several known carcinogenic substances and its carcinogenic effect is biologically plausible [4, 6]. Abundant evidence exists on exposure-response relation between ETS and the risk of lung cancer. Selection or information biases or confounding may have affected the risk estimates of lung cancer to some extent, but they do not explain the observed relations completely, and their effects tend to cancel out when adjustments are made for them. 
a)

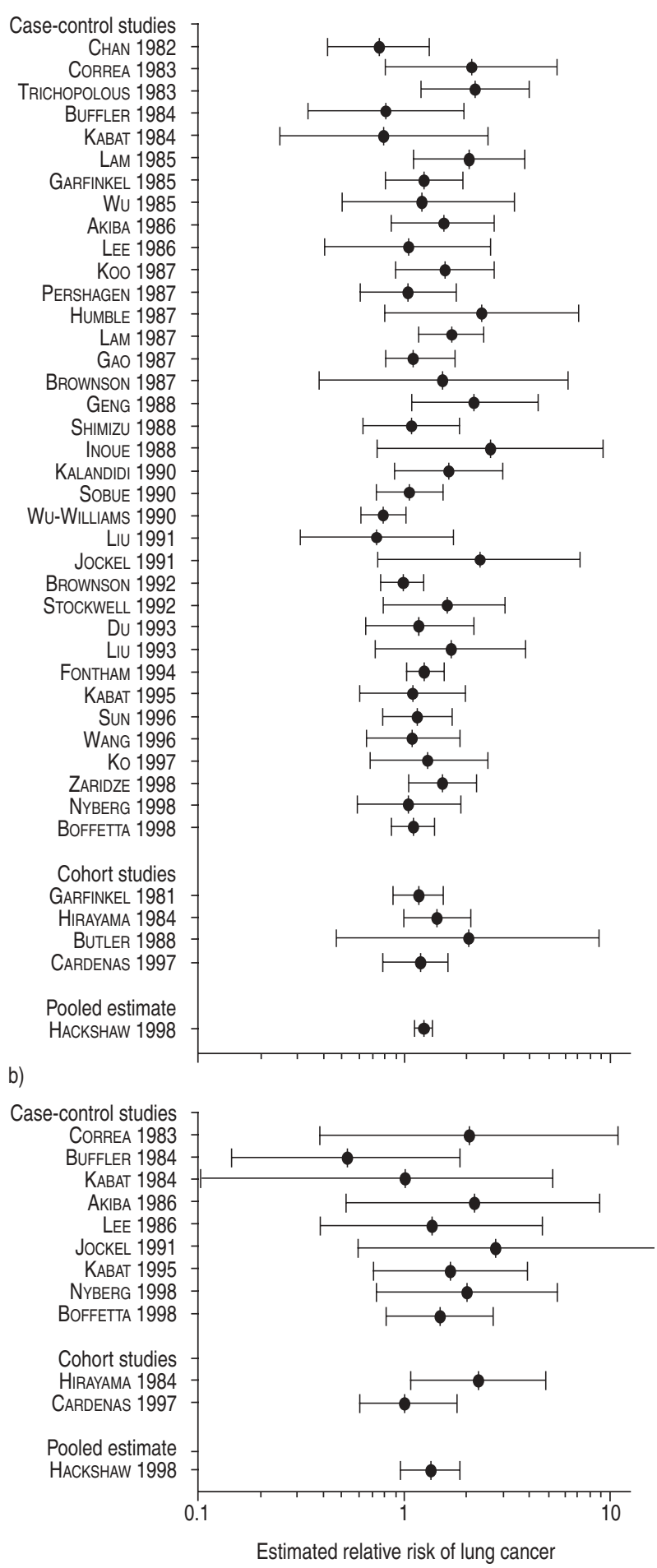

Fig. 1.-Relative risk estimates (rate ratio, risk ratio or odds ratio) of lung cancer and their 95\% confidence intervals for spousal smoking in nonsmoking a) females and b) males from studies published by October 1998. The studies are grouped into casecontrol and cohort studies. For each study, the first author and the publishing year is given. The pooled estimate is from a metaanalysis by HACKSHAW et al. [58], and it includes all studies except KO et al. 1997 [45], ZARIDZE et al. 1998 [46], NYBERG et al. 1998 [48] and BOFFETTA et al. 1998 [49] for females and NYBERG et al. 1998 [48] and BOFFETTA et al. 1998 [49] for males.

\section{Chronic respiratory symptoms}

A total of 12 cross-sectional [63-74] and two longitudinal studies $[75,76]$ addressed the role of ETS exposure in the development of chronic respiratory symptoms in adults, but many of the studies focussed on younger age groups. Only seven crosssectional studies included subjects aged $>60$ yrs [65-69, 71, 73], while none were designed to address the effects of ETS in particular in the elderly. Most of the studies assessed household ETS exposure, while two assessed workplace exposures [69, 73]. All seven studies, except one [65], showed an increased risk of chronic respiratory symptoms, including cough, phlegm production, wheezing, and breathlessness, in relation to ETS exposure at home and/or in the workplace, although not all reached statistical significance $[67,68]$. The excess risk of symptoms related to ETS varied between $35 \%$ and $>300 \%$ (table 1 ).

A study of females from Singapore showed doseresponse relations between the number of household smokers and the risk of cough, wheezing and dyspnoea [71]. A study from Sweden included 205 never-smokers with severe $\alpha_{1}$-antitrypsin deficiency (with PiZZ genotype), who were suggested to be especially susceptible to the adverse effects of ETS [73]. Significantly increased risk was observed for chronic bronchitis in relation to ETS exposure.

In conclusion, based on seven cross-sectional studies from different countries, ETS exposure appears to cause chronic respiratory symptoms in the elderly [4]. This is biologically plausible, since tobacco smoke is known to contain several irritative compounds, such as ammonia, sulphur dioxide, nitrogen oxides, acrolein, and formaldehyde [6, 7]. In addition, active smoking is known to cause chronic respiratory symptoms [5]. All of the studies adjusted for confounders, although for a variable set of them, including age, sex, socioeconomic status, occupational exposures, and other indoor sources of pollution. However, longitudinal studies focussing on the older age groups are needed.

\section{Lung function}

Altogether 20 cross-sectional studies [64, 65, 67, 68, 71, 77-91], one case-control study [92], and four longitudinal studies [81, 90, 93, 94] have addressed the relations between ETS exposure and ventilatory lung function in adulthood. A meta-analysis including nine of the cross-sectional studies estimated the effect of ETS on forced expiratory volume in one second (FEV1) to be $-2.7 \%(95 \%$ CI $-4.1--1.2 \%)$ (table 1) [90]. However, most of the adult studies focussed on younger age groups. Only 10 cross-sectional studies $[65,67,68,71,84-87,89,90]$ and one longitudinal study [90] included subjects aged $>60$ yrs.

The results on lung function have been somewhat inconsistent. The majority of the studies detected significant adverse effects on FEV1, forced vital capacity (FVC), and/or indices of small airways function in relation to home and/or workplace ETS exposure $[67,71,84,86,90]$. The harmful effect on 
FEV1 was from $-50 \mathrm{~mL}$ in the Singapore study [71] to $-257 \mathrm{~mL}$ in the China study [86]. All but one crosssectional study assessed exposure from household sources, while three studies assessed workplace ETS exposure [84, 86, 89]. Two of the cross-sectional studies focussed especially on the elderly and showed no significant effects of household smoking on lung function, but both are likely to have been hampered by survival bias [85, 87]. Two studies showed a significant dose-response relations between the amount of household smoking and reduction in FEV1 $[86,90]$. The only longitudinal study including the elderly did not find any significant effect of ETS on the change in lung function in a 7-yr follow-up (table 1) [90].

A study from California addressed the effects of ETS on peak expiratory flow (PEF) variability [89]. This variability was significantly increased among males who had worked for 10 yrs with a smoker.

In conclusion, several cross-sectional studies including the elderly indicate small, but significant, reductions in ventilatory function parameters among subjects exposed to ETS at home and/or in the workplace. This effect seems to be dose-dependent, and is observed mainly in countries and in occupations with high ETS exposure levels. Exposure misclassification and confounding do not explain the observed relations. Most of the studies controlled for sex, age, height, socioeconomic status and/or education. Some also adjusted for housing conditions and other indoor air pollutants, occupational exposures, and outdoor air pollutants. The well-known effects of active smoking on lung-function impairment support the biological plausibility of the adverse effects of ETS [5]. It is possible that the small effects on lung function detected in several cross-sectional studies are due to a susceptible group experiencing a more pronounced lung-function deficit in relation to ETS exposure. Potential determinants of susceptibility should be studied in the future. A limited number of studies focussing on elderly populations have been carried out, and there is a need for more longitudinal studies.

\section{Asthma}

Six epidemiological studies have addressed the role of ETS in induction of asthma in adulthood [71, 72, 95-98]. Four of them [71, 95, 96, 98] included subjects $>60$ yrs. All four studies found an increased risk of asthma in relation to ETS exposure, although the effect reached statistical significance in only two studies [95, 98]. All three studies that included assessment of workplace ETS exposure found an increased risk of asthma related to workplace exposure $[95,96,98]$. The excess risk of asthma related to ETS was estimated to be $45-100 \%$ (table 1). Two studies based the definition of asthma on objective measurements [96, 98]. In the Swedish study, a potential problem was inclusion of active smokers in the study population [96].

A 10-yr longitudinal study among the Seventh-Day Adventists from USA reported an OR of $1.45(95 \%$ CI 1.21-1.80) for asthma in relation to $10 \mathrm{yrs}$ of workplace ETS exposure [95]. In a 15-yr follow-up of this cohort, the OR was 1.21 per 7 yrs of workplace ETS exposure (95\% CI 1.04-1.39) among females [99]. The slight reduction in the risk estimate probably reflects selective loss of subjects who were more likely to have asthma and high levels of ETS. This type of survival bias is of concern especially in studies of the elderly.

In conclusion, a limited number of studies have been published on ETS and development of asthma in the elderly, but they consistently indicate an increased risk of asthma among those exposed to ETS at home or at work. All studies controlled for confounding, although the set of confounders was variable. Factors that were controlled included age, sex, education, occupational exposures, atopy, and outdoor air pollution. Only two studies based the definition of asthma on objective measurements. Potential mechanisms by which ETS could induce asthma include an inflammatory reaction in the airways related to the irritative substances contained by ETS, which would be a similar type of mechanism as has been shown in the case of irritant-induced occupational asthma [100]. Skin-test positivity to tobacco is rare [101-103], and the effect of ETS on asthma seems to occur via irritative rather than allergic mechanisms. Tobacco smoke may also increase epithelial permeability to environmental allergens, thus enhancing allergic reactions to other inhalable allergens [104, 105]. Before making any definite conclusions, more studies among adults, and especially among the elderly, are needed.

\section{Chronic obstructive pulmonary disease}

Chronic obstructive pulmonary disease develops slowly over the years and is often diagnosed in older age. Three case-control [106-108] and three longitudinal studies $[2,109,110]$ have investigated the effects of ETS on development of or mortality from COPD. All of them included subjects aged $\geqslant 60 \mathrm{yrs}$. COPD was defined in variable ways, based on symptoms and/or diagnoses made by a doctor reported in questionnaires, lung function measurements, mortality registers, or a combination of these. An increased risk of COPD was found in all six studies, at least in the high ETS exposure categories. The excess risk related to ETS exposure was estimated to be from $60 \%$ to $>400 \%$ (table 1 ). Workplace ETS exposure was assessed in the longitudinal study of Seventh-Day Adventists from USA [110, 111], while the others limited exposure assessment to household only.

In conclusion, a limited number of studies have addressed the relation between ETS exposure and development of COPD, but all of them showed an increased risk. Dose-response relation was suggested by four studies $[2,107,108,110]$. Age and sex were taken into account as potential confounders in all of the studies, the other factors adjusted for included the participant's own or spouse's occupation, housing quality, other indoor pollutants, and outdoor pollution. Tobacco smoke has been demonstrated to induce 
inflammatory reactions in the airways and lung parenchyma of active smokers [112-114] and the biological effects of ETS are likely to be similar to those of the mainstream smoke. More studies with better outcome and exposure assessment are needed before any definite conclusions can be made.

\section{Respiratory infections}

There is convincing evidence of the role of passive smoking in enhancing susceptibility to respiratory infections in children [4, 115], but only one study addressed infections in adults [116]. This populationbased case-control study from USA investigated the effects of tobacco smoke on pneumococcal bacteraemia and meningitis in adults aged 18-64 yrs. The estimated OR for ETS exposure was 2.5 (95\% CI 1.2-5.1) (table 1), adjusted for sex, race, presence of chronic illnesses, education, and living with children going to day care. The population attributable risk for passive smoking was $17 \%$. A dose-response relation was observed between the hours of daily ETS exposure and the risk of invasive pneumococcal disease.

There may be several mechanisms by which ETS increases susceptibility to infections: tobacco smoke impairs host defence mechanisms through weakening of immunological responses and mucociliary clearance $[5,117,118]$ and tobacco smoke has been shown to enhance bacterial adherence and to disrupt respiratory epithelium [119, 120]. More studies are needed addressing the relations between ETS exposure and infections in adulthood, especially among the elderly.

\section{Coronary heart disease}

A recent meta-analysis including nine prospective and 10 case-control studies estimated the risk of coronary heart diseases (CHD) in relation to ETS exposure at home [121]. The OR was $1.30(95 \% \mathrm{CI}$ $1.22-1.38$ ) at the age of 65 yrs (table 1). Another meta-analysis, based on eight case-control and nine cohort studies, yielded a risk estimate of 1.25 (1.17-1.33) related to spouse's smoking [122]. Most of the studies included the elderly or had a long follow-up extending into the older ages. The effect across the studies appeared to be consistent and was not weakened by adjusting for potential confounders in these studies [122]. Several studies found an increasing risk of CHD in relation to the number of cigarettes smoked by the spouse and the duration of exposure [122]. STEENLAND [123] carried out a meta-analysis of three cohort and two case-controls studies reporting ORs for ETS exposure at work. The estimated pooled risk ratio was 1.21 (95\% CI 1.04 1.41) (table 1).

In conclusion, there is accumulating evidence suggesting that ETS exposure at home [121, 122] and in the workplace $[123,124]$ causes coronary heart disease. The size of the risk estimates for ETS seem quite high compared to the estimates for active smoking, but there are several biologically plausible explanations for this. Many of the substances linked to CHD are in the vapour phase in ETS, but in the particle phase in mainstream smoke, so they are deposited more completely in the lungs and are harder to clear than particle deposits [125]. Experimental studies have shown that ETS causes platelet activation and endothelial injury and suggest that passive smokers are less able to adapt to the adverse effects of toxins of tobacco smoke than active smokers are [126-128].

\section{Stroke}

The association of active smoking with cerebrovascular stroke has been demonstrated in many studies and is likely to be causal [129, 130]. Two case-control studies, both including the elderly, have addressed the relations of ETS exposure with the risk of cerebral ischaemia [130, 131]. In a hospital-based case-control of subjects aged 20-87 yrs, exposure to a smoking spouse was an independent risk factor for cerebral ischaemia, with an OR of 1.7 (95\% CI 1.1-2.6) [130]. The Auckland Stroke Study was a population-based case-control study among the age group 35-74 yrs [131]. Nonsmokers exposed to ETS at home and/or at work had a significantly increased stroke incidence and fatality in males (OR 2.10, 95\% CI 1.33-3.32) and in females (OR 1.66, 95\% CI 1.07-2.57), after adjusting for known risk factors of stroke, such as hypertension, diabetes, and heart disease (table 1). In conclusion, these two studies suggest an independent effect of ETS exposure on the risk of stroke.

\section{Prognostic studies of environmental tobacco smoke exposure in the elderly}

\section{Chronic respiratory symptoms}

No study was identified on the role of ETS in determining persistence or remission of chronic respiratory symptoms in the elderly. A cross-sectional study of 2,992 adults from the UK assessed respiratory symptom severity across smoking categories, combining several symptoms and their frequency in the past month [132]. The median score was 2.8 for never-smokers and 4.2 for passive smokers. The adjusted OR of severe symptoms was 1.4 (95\% CI $1.0-1.8)$ in relation to current household ETS exposure.

\section{Lung function}

A study from California examined a relatively young population of bartenders before and after prohibition of smoking in bars [133]. The mean age of this population was 43 yrs. Cessation or reduction of ETS exposure at work led to an improved FEV1 and FVC. No study has addressed the potential 
prognostic effects on lung function development of reducing ETS exposure in the elderly.

\section{Asthma}

In community- and hospital-based surveys, 69-78\% of asthma patients report that cigarette smoke aggravates their asthmatic symptoms [134-136]. Six epidemiological studies [91, 137-141] have addressed the effects of ETS on pre-existing asthma in adults, but only one of these included subjects aged $>60 \mathrm{yrs}$ [137]. The studies on younger age groups detected increased need of asthma medications, increased number of emergency department visits, urgent physician visits, and hospitalizations, increased work-related asthmatic symptoms, and lower FEV1 and forced mid-expiratory flow levels in relation to ETS exposure [138-140]. In a panel study of 164 asthmatic nonsmokers aged 18-70 yrs from USA, daily ETS exposure was significantly related to an increased risk of moderate or severe cough (OR 1.21, 95\% 1.01-1.46), moderate or severe breathlessness (OR $1.85,95 \%$ CI 1.57-2.18), and nocturnal asthma symptoms (OR $1.24,95 \%$ CI 1.00-1.53) [137]. In addition to the epidemiological studies, several experimental studies, usually focussing on younger age groups, have suggested that there is a subpopulation of asthmatics who are sensitive to ETS [4, 102]. These asthmatics experience increased respiratory symptoms, decreased lung function and increased bronchial hyperresponsiveness in response to ETS exposure. The determinants of such susceptibility are not well understood.

In conclusion, a limited number of epidemiological studies and several experimental studies, almost all of which have focussed on younger age groups, suggest that ETS exposure contributes to severity and exacerbations of asthma among adult asthmatics. The elderly were included in only one study. Thus, prognostic studies on effects of ETS on pre-existing asthma in the elderly are needed.

\section{Chronic obstructive pulmonary disease}

No study was identified on the effects of ETS on the long-term prognosis of COPD. Two studies assessed the impact of ETS exposure on respiratory-related activity restrictions [142, 143]. Both of these studies used data collected in the US National Health Interview Surveys conducted by the Census Bureau for the National Center for Health Statistics. In the first study, respiratory-related restricted activity in the past 2 weeks increased among nonsmokers on average by $1 \%$ per exposure to one cigarette per day at home [142]. In the other study, respiratory disease exacerbation was defined as activity limitation or physician visit in the preceding 2 weeks because of chronic bronchitis, asthma, emphysema, or chronic sinusitis [143]. It increased significantly in relation to ETS exposure at home and/or work, with an OR of 1.44 (95\% CI 1.07-1.95) adjusted for age, sex, season, socioeconomic status, and race. In conclusion, these two studies suggest that ETS exposure contributes to the adverse consequences of COPD, but there is a lack of prognostic studies on COPD.

\section{Coronary heart disease}

Experimental studies have demonstrated among patients with stable angina that ETS exposure increases heart rate, blood pressure, and blood carboxyhaemoglobin, and reduces exercise ability [127, 128]. Again, there is lack of epidemiological studies assessing the role of ETS as a long-term prognostic factor in subjects with pre-existing heart disease.

\section{Summary and questions for future research}

Table 1 summarizes the evidence from aetiological studies on ETS in adults. The risk estimates are from published meta-analyses when available or from individual studies including the elderly. Abundant studies have been published on lung cancer and CHD, while aetiological research on the other health effects in adults has only recently received attention. Few studies on the noncarcinogenic respiratory health effects have focussed on the elderly.

Surprisingly, few studies have evaluated the role of ETS in determining the prognosis of pre-existing diseases. The effects of ETS on prognosis of diseases may have a critical impact on the functional capacity and quality of life among the elderly, but there is a lack of such studies in elderly populations.

\section{Questions for future research}

The evidence on the aetiological role of ETS in asthma, lung function impairment, COPD, respiratory infections, and stroke is suggestive but limited, and there is a clear need for more aetiological studies on these diseases and conditions in the elderly. Since selective survival of healthy (and unexposed) subjects is of special concern in studies of older age groups, longitudinal studies initiated in younger age periods and followed through the older age periods are needed. Focussing on high-quality assessment of both ETS exposure and disease condition in question is essential for achieving valid and precise risk estimates. Exposure assessment should take the relevant exposure period into account, which is often different in aetiological and in prognostic studies [11]. For all health effects characteristics that determine susceptibility to the adverse effects of ETS should be studied. As a part of identifying especially sensitive subgroups, potential interactions between ETS and other environmental exposures should be addressed in the future. For example, previous occupational exposures may increase susceptibility of the elderly to adverse effects of ETS.

The potential role of environmental tobacco smoke exposure as a prognostic factor determining the development of a pre-existing respiratory or ischaemic heart disease is an important new area for research. Such research is likely to "throw light" on the harmful 
impact of environmental tobacco smoke especially among the elderly, who often have chronic diseases and may be exposed to high environmental tobacco smoke levels because of activity limitations related to these diseases.

\section{References}

1. U.S. Dept of Health and Human Services. Reducing the health consequences of smoking: 25 years of progress. A report of the Surgeon General. U.S. Dept of Health and Human Services, Public Health Service, Centers for Disease Control, Center for Chronic Disease Prevention and Health Promotion, Office on Smoking and Health. DHHS Publication No. (CDC) 89-8411, 1989.

2. Hirayama T. Non-smoking wives of heavy smokers have a higher risk of lung cancer: a study from Japan. Br Med J Clin Res Ed 1981; 282: 183-185.

3. Trichopoulos D, Kalandidi A, Sparros L, MacMahon B. Lung cancer and passive smoking. Int $J$ Cancer 1981; 27: 1-4.

4. Jaakkola MS. Environmental tobacco smoke and respiratory diseases. Eur Respir Monograph 2000; 15: 322-383.

5. U.S. Dept of Health and Human Services. The health consequences of smoking: chronic obstructive pulmonary disease. A report of the Surgeon General. U.S. Dept of Health and Human Services, Public Health Service, Office of the Assistant Secretary for Health, Office of Smoking and Health. DHHS Publication No. 84-50205, 1984.

6. U.S. Environmental Protection Agency. Respiratory health effects of passive smoking: lung cancer and other disorders. U.S. Environmental Protection Agency, Office of Health and Environmental Assessment, Office of Research and Development. Washington DC, 1992. EPA/600/6-90/006F.

7. Hoffmann D, Hoffmann I. The changing cigarette, 1950-1995. J Toxicol Environ Health 1997; 50: $307-$ 364.

8. Riboli E, Preston-Martin S, Saracci R, et al. Exposure of nonsmoking women to environmental tobacco smoke: a 10-country collaborative study. Cancer Causes Control 1990; 1: 243-252.

9. Pirkle JL, Flegal KM, Bernert JT, Brody DJ, Etzel RA, Maurer KR. Exposure of the US population to environmental tobacco smoke. The Third National Health and Nutrition Examination Survey, 1988 to 1991. JAMA 1996; 275: 1233-1240.

10. Jaakkola MS, Jaakkola JJK. Assessment of exposure to environmental tobacco smoke. Eur Respir J 1997; 10: 2384-2397.

11. Jaakkola MS, Samet JM. Occupational exposure to environmental tobacco smoke and health risk assessment. Environ Health Perspect 1999; 107: Suppl. 6, 829-835.

12. Chan WC, Fung SC. Lung cancer in non-smokers in Hong Kong. In: Grundman E, ed. Cancer Campaign. Vol. 6. Cancer epidemiology. New York, Gustav Fischer, 1982; pp. 199-202.

13. Correa P, Pickle LW, Fontham E, Lin Y, Haenszel W. Passive smoking and lung cancer. Lancet 1983; ii: 595-597.

14. Trichopoulos D, Kalandidi A, Sparros L. Lung cancer and passive smoking: conclusion of the Greek study. Lancet 1983; ii: 677-678.

15. Buffler PA, Pickle LW, Mason TJ, Contant C. The causes of lung cancer in Texas. In: Mizell M, Corres P, eds. Lung Cancer Causes and Prevention. New York, Verlag Chemie International, 1984; pp. 83-99.

16. Kabat GC, Wynder EL. Lung cancer in nonsmokers. Cancer 1984; 53: 1214-1221.

17. Lam WK. A clinical and epidemiological study of carcinoma of the lung in Hong Kong. Hong Kong, University of Hong Kong, 1985 (PhD thesis).

18. Garfinkel L, Auerbach O, Joubert L. Involuntary smoking and lung cancer: a case-control study. J Natl Cancer Inst 1985; 75: 463-469.

19. Wu A, Henderson BE, Pike MC, Yu MC. Smoking and other risk factors for lung cancer in women. $J$ Natl Cancer Inst 1985; 74: 747-749.

20. Akiba S, Kato H, Blot WJ. Passive smoking and lung cancer among Japanese women. Cancer Res 1986; 46: $4804-4807$.

21. Lee PN, Chamberlain J, Alderson MR. Relationship of passive smoking to risk of lung cancer and other smoking-associated diseases. Br J Cancer 1986; 54: 97-105.

22. Koo LC, Ho JHC, Saw D, Ho C. Measurements of passive smoking and estimates of lung cancer risk among non-smoking Chinese females. Int $J$ Cancer 1987; 39: 162-169.

23. Pershagen G, Hrubec Z, Svensson C. Passive smoking and lung cancer in Swedish women. Am J Epidemiol 1987; 125: 17-24.

24. Humble CG, Samet JK, Pathak DR. Marriage to a smoke and lung cancer risk. Am J Public Health 1987; 77: 5989-6602.

25. Lam TH, Kung ITM, Wong CM, et al. Smoking, passive smoking and histological types in lung cancer in Hong Kong Chinese women. Br J Cancer 1987; 56: 673-678.

26. Gao Y-T, Blot WJ, Zheng W, et al. Lung cancer among Chinese women. Int J Cancer 1987; 40: 604609.

27. Brownson RC, Reif JS, Keefe TJ, Ferguson SW, Pritzl JA. Risk factors for adenocarcinoma of the lung. $\mathrm{Am}$ J Epidemiol 1987; 125: 25-34.

28. Geng G, Liang ZH, Zhang AY, Wu GL. On the relationship between smoking and female lung cancer. In: Aoki M, Hisamichi S, Tominaga S, eds. Smoking and Health. Amsterdam, Elsevier Science, 1988; pp. 483-486.

29. Shimizu H, Morishita M, Mizuno K, et al. A casecontrol study of lung cancer in non-smoking women. Tohoku J Exp Med 1988; 154: 389-397.

30. Inoue R, Hirayama T. Passive smoking and lung cancer in women. In: Aoki M, Hisamichi S, Tominaga $\mathrm{S}$, eds. Smoking and Health. Amsterdam, Elsevier Science, 1988, pp. 283-285.

31. Svensson C, Pershagen G, Klominek J. Smoking and passive smoking in relation to lung cancer in women. Acta Oncol 1989; 28: 623-629.

32. Janerich DT, Thompson WD, Varela LR, et al. Lung cancer and exposure to tobacco smoke in the household. N Engl J Med 1990; 323: 632-636.

33. Kalandidi A, Katsouyanni K, Voropoulou N, Bastas G, Saracci R, Trichpolous D. Passive smoking and diet in the etiology of lung cancer among non-smokers. Cancer Causes Control 1990; 1: 15-21.

34. Sobue T. Association of indoor air pollution and 
lifestyle with lung cancer in Osaka, Japan. Int J Epidemiol 1990; 19: S62-S66.

35. Wu-Williams AH, Dai XD, Blot W, et al. Lung cancer among women in Northeast China. Br J Cancer 1990; 62: $982-987$.

36. Liu Z, He X, Chapman RS. Smoking and other risk factors for lung cancer in Xuanwei, China. Int J Epidemiol 1991; 20: 26-31.

37. Brownson RC, Alavanja MCR, Hock ET, Loy TS. Passive smoking and lung cancer in nonsmoking women. Am J Public Health 1992; 82: 1525-1530.

38. Stockwell HG, Goldman AL, Lyman GH, et al. Environmental tobacco smoke and lung cancer risk in nonsmoking women. J Natl Cancer Inst 1992; 84: 1417-1422.

39. Du YX, Cha Q, Chen YZ, Wu JM. Exposure to environmental tobacco smoke and female lung cancers in Guangzhou, China. In: Jaakkola JJK, Ilmarinen R, Seppänen O, eds. Indoor Air '93. Vol. 1: Health effects. Proceedings of the 6th International Conference on Indoor Air Quality and Climate. Jyväskylä, Gummerus Oy, 1993; 1: 511-516.

40. Liu Q, Sasco AJ, Riboli E, Hu MX. Indoor air pollution and lung cancer in Guangzhou, People's Republic of China. Am J Epidemiol 1993; 137: 145-154.

41. Fontham ETH, Correa P, Reynolds P, et al. Environmental tobacco smoke and lung cancer in nonsmoking women. A multicenter study. JAMA 1994; 271: 17521759.

42. Kabat GC, Stellman SD, Wynder EL. Relation between exposure to environmental tobacco smoke and lung cancer in lifetime nonsmokers. $A m J$ Epidemiol 1995; 142: 141-148.

43. Sun $X-W$, Dai $X-D$, Lin $C-Y$, Shi $Y-B$, Ma Y-Y, $\mathrm{Li}$ W. Passive smoking and lung cancer among nonsmoking women in Harbin, China. International symposium on lifestyle factors and human lung cancer, China 1996. Lung Cancer 1996; 14: S237.

44. Wang T-J, Zhou B-S, Shi J-P. Lung cancer in nonsmoking Chinese women: a case-control study. International symposium on lifestyle factors and human lung cancer, China 1996. Lung Cancer 1996; 14: S93-S98.

45. Ko Y-C, Lee C-H, Chen M-J, et al. Risk factors for primary lung cancer among non-smoking women in Taiwan. Int J Epidemiol 1997; 26: 24-31.

46. Zaridze D, Maximovitch D, Zemlyanaya G, Aitokov $\mathrm{ZN}$, Boffetta P. Exposure to environmental tobacco smoke and risk of lung cancer in non-smoking women from Moscow, Russia. Int J Cancer 1998; 75: 335-338.

47. Jöckel K-H, Pohlabeln H, Ahrens W, Krauss M. Environmental tobacco smoke and lung cancer. Epidemiology 1998; 9: 672-675.

48. Nyberg F, Agrenius V, Svartengren K, Svensson C, Pershagen G. Environmental tobacco smoke and lung cancer in nonsmokers: Does time since exposure play a role? Epidemiology 1998; 9: 301-308.

49. Boffetta P, Agudo A, Ahrens W, et al. Multicenter case-control study of exposure to environmental tobacco smoke and lung cancer in Europe. $J$ Natl Cancer Inst 1998; 90: 1440-1450.

50. Garfinkel L. Time trends in lung cancer mortality among nonsmokers and a note on passive smoking. J Natl Cancer Inst 1981; 66: 1061-1066.

51. Hirayama T. Cancer mortality in nonsmoking women with smoking husbands based on a large-scale cohort study in Japan. Prev Med 1984; 13: 680-690.
52. Butler TL. The relationship of passive smoking to various health outcomes among Seventh-Day Adventists in California. University of California, Los Angeles, 1988 (Dissertation).

53. Hole DJ, Gillis CR, Chopra C, Hawthrone VM. Passive smoking and cardiorespiratory health in a general population in the west of Scotland. $\mathrm{Br}$ Med $J$ 1989; 299: 423-427.

54. Cardenas VM, Thun MJ, Austin H, et al. Environmental tobacco smoke and lung cancer mortality in the American Cancer Society's cancer prevention study II. Cancer Causes Control 1997; 8: 57-64.

55. Wald NJ, Nanchahal K, Thompson SG, Cuckle HS. Does breathing other people's tobacco smoke cause lung cancer? BMJ 1986; 293: 1217-1222.

56. Vainio H, Partanen T. Population burden of lung cancer due to environmental tobacco smoke. Mutation Res 1989; 222: 137-140.

57. Saracci R, Riboli E. Passive smoking and lung cancer: current evidence and ongoing studies at the International Agency for Research on Cancer. Mutation Res 1989; 222: 117-127.

58. Hackshaw AK, Law MR, Wald NJ. The accumulated evidence on lung cancer and environmental tobacco smoke. BMJ 1997; 315: 980-988.

59. Wells AJ. Lung cancer from passive smoking at work. Am J Public Health 1998; 88: 1025-1029.

60. Brown KG. Lung cancer and environmental tobacco smoke: Occupational risk to nonsmokers. Environ Health Perspect 1999; 107: Suppl. 6, 885-890.

61. Koo LC, Ho JHC, Saw D. Is passive smoking an added risk factor for lung cancer in Chinese women? J Exp Clin Cancer Res 1984; 3: 277-283.

62. Reynolds P. Epidemiologic evidence for workplace ETS as a risk factor for lung cancer among nonsmokers: specific risk estimates. Environ Health Perspect 1999; 107: Suppl. 6, 865-872.

63. Lebowitz MD, Burrows B. Respiratory symptoms related to smoking habits of family adults. Chest 1976; 69: 48-50

64. Schilling RSF, Letai AD, Hui SL, Beck JB, Schoenberg JB, Bouhuys A. Lung function, respiratory disease, and smoking in families. Am J Epidemiol 1977; 106: 274-283.

65. Comstock GW, Meyer MB, Helsing KJ, Tockman MS. Respiratory effects of household exposures to tobacco smoke and gas cooking. Am Rev Respir Dis 1981; 124: 143-148.

66. Schenker MB, Samet JM, Speizer FE. Effect of cigarette tar content and smoking habits on respiratory symptoms in women. Am Rev Respir Dis 1982; 125: $684-690$

67. Hole DJ, Gillis CR, Chopra C, Hawthrone VM. Passive smoking and cardiorespiratory health in a general population in the west of Scotland. BMJ 1989; 299: 423-427.

68. Kauffman F, Dockery DW, Speizer FE, Ferris BG. Respiratory symptoms and lung function in relation to passive smoking: A comparative study of American and French women. Intern J Epidemiol 1989; 18: 334 344.

69. White JR, Froeb HF, Kulik JA. Respiratory illness in nonsmokers chronically exposed to tobacco smoke in the work place. Chest 1991; 100: 39-43.

70. Pope CA 3rd, Xu X. Passive cigarette smoke, coal heating, and respiratory symptoms of nonsmoking 
women in China. Environ Health Perspect 1993; 101: 314-316.

71. Ng TP, Hui KP, Wan C Tan. Respiratory symptoms and lung function effects of domestic exposure to tobacco smoke and cooking by gas in non-smoking women in Singapore. J Epidemiol Community Health 1993; 47: 454-459.

72. Leuenberger P, Schwartz J, Ackermann-Liebrich U, et al. Passive smoking exposure in adults and chronic respiratory symptoms (SAPALDIA Study). Am J Respir Crit Care Med 1994; 150: 1222-1228.

73. Piitulainen E, Tornling G, Eriksson S. Environmental correlates of impaired lung function in non-smokers with severe $\alpha 1$-antitrypsin deficiency (PiZZ). Thorax 1998; 53: 939-943.

74. Lam TH, Ho LM, Hedley AJ, et al. Environmental tobacco smoke exposure among police officers in Hong Kong. JAMA 2000; 284: 756-763.

75. Schwartz J, Zeger S. Passive smoking, air pollution, and acute respiratory symptoms in a diary study of student nurses. Am Rev Respir Dis 1990; 141: 62-67.

76. Jaakkola MS, Jaakkola JJK, Becklake MR, Ernst P. Effect of passive smoking on the development of respiratory symptoms in young adults: An 8-year longitudinal study. J Clin Epidemiol 1996; 49: 581-586.

77. White JR, Froeb HF. Small-airways dysfunction in nonsmokers chronically exposed to tobacco smoke. $N$ Engl J Med 1980; 302: 720-723.

78. Kauffman F, Teshier J-F, Oriol P. Adult passive smoking in the home environment: A risk factor for chronic airflow limitation. Am J Epidemiol 1983; 117 : 269-280.

79. Kentner M, Triebig G, Weltle D. The influence of passive smoking on pulmonary function-A study of 1,351 office workers. Prev Med 1984; 13: 656-669.

80. Salem ES, El Zahby M, Senna GA, Malek A. Pulmonary manifestations among passive smokers. Bull Int Union Tuberc 1984; 59: 50-53.

81. Brunekreef B, Fischer P, Remijn B, Van Der Lende R, Schouten J, Quanjer P. Indoor air pollution and its effect on pulmonary function of adult non-smoking women: III. Passive smoking and pulmonary function. Intern J Epidemiol 1985; 14: 227-230.

82. Svendsen KH, Kuller LH, Martin MJ, Ockene JK. Effects of passive smoking in the multiple risk factor intervention trial. Am J Epidemiol 1987; 126: 783-795.

83. Masi MA, Hanley JA, Ernst P, Becklake MR. Environmental tobacco smoke and lung function in young adults. Am Rev Respir Dis 1988; 138: 296-299.

84. Masjedi M-R, Kazemi H, Johnson DC. Effects of passive smoking on the pulmonary function in adults. Thorax 1990; 45: 27-31.

85. Higgins MW, Enright PL, Kronmal RA, Schenker MB, Anton-Culver H, Lyles M. Smoking and lung function in elderly men and women. JAMA 1993; 269: 2741-2748.

86. Xu X, Li B. Exposure-response relationship between passive smoking and adult pulmonary function. $\mathrm{Am}$ J Respir Crit Care Med 1995; 151: 41-46.

87. Frette C, Barrett-Connor E, Clausen JL. Effect of active and passive smoking on ventilatory function in elderly men and women. Am J Epidemiol 1996; 143: 757-765.

88. Casale R, Pasqualetti P. Cosinor analysis of circadian peak expiratory flow variability in normal subjects, passive smokers, heavy smokers, patients with chronic obstructive pulmonary disease and patients with interstitial lung disease. Respiration 1997; 64: 251-256.

89. Abbey DE, Burchette RJ, Knutsen SF, McDonnell WF, Lebowitz MD, Enright PL. Long-term particulate and other air pollutants and lung function in nonsmokers. Am J Respir Crit Care Med 1998; 158: 289-298.

90. Carey IM, Cook DG, Strachan DP. The effects of environmental tobacco smoke exposure on lung function in a longitudinal study of British adults. Epidemiology 1999; 10: 319-326.

91. Künzli N, Schwartz J, Zemp Stutz E, AckermannLiebrich U, Leuenberger P. Association of environmental tobacco smoke at work and forced expiratory lung function among never smoking asthmatics and non-asthmatics. Sozial- und Präventivmedizin 2000; 45: 208-217.

92. Jones JR, Higgins JTT, Higgins MW, Keller JB. Effects of cooking fuels on lung function in nonsmoking women. Arch Environ Health 1983; 38: 219-222.

93. Lebowitz MD. Influence of passive smoking on pulmonary function: A survey. Prev Med 1984; 13: 645-655.

94. Jaakkola MS, Jaakkola JJK, Becklake MR, Ernst P. Passive smoking and evolution of lung function in young adults: An 8-year longitudinal study. J Clin Epidemiol 1995; 48: 317-327.

95. Greer JR, Abbey DE, Burchette RJ. Asthma related to occupational and ambient air pollutants in nonsmokers. J Occup Med 1993; 35: 909-915.

96. Flodin U, Jönsson P, Ziegler J, Axelson O. An epidemiologic study of bronchial asthma and smoking. Epidemiology 1995; 6: 503-505.

97. Hu FB, Persky V, Flay BR, Richardson J. An epidemiological study of asthma prevalence and related factors among young adults. J Asthma 1997; 34: 67-76.

98. Jaakkola MS, Piipari R, Jaakkola N, Jaakkola JJK. Environmental tobacco smoke and adult-onset asthma: a population-based incident case-control study. Eur Respir J 2001; 18: Suppl. 33, 285s.

99. McDonnell WF, Abbey DE, Nishino N, Lebowitz MD. Long-term ambient ozone concentration and the incidence of asthma in nonsmoking adults: the AHSMOG Study. Environ Res 1999; 80: 110-121.

100. Tarlo SM, Broder I. Irritant-induce occupational asthma. Chest 1989; 96: 297-300.

101. Tredaniel J, Boffetta P, Saracci R, Hirsch A. Exposure to environmental tobacco smoke and adult nonneoplastic respiratory diseases. Eur Respir J 1994; 7: 173-185.

102. California Environmental Protection Agency. Office of Environmental Health Hazard Assessment. Health effects of exposure to environmental tobacco smoke. California, 1997.

103. Stankus RP, Menon PK, Rando RJ, Glindmeyer H, Salvaggio JE, Lehrer SB. Cigarette smoke sensitive asthma: challenge studies. J Allergy Clin Immunol 1988; 82: 331-338.

104. Zetterström O, Österman K, Machado L, Johansson SGO. Another smoking hazard: Raised serum IgE concentrations and increased risk of occupational allergy. BMJ 1981; 283: 1215-1220.

105. Kjellman NIM. Effect of parental smoking on IgE levels in children. Lancet 1981; i: 993-994.

106. Lee PN, Chamberlain J, Alderson MR. Relationship of passive smoking to risk of lung cancer and other smoking-associated diseases. Br J Cancer 1986; 54: 97-105.

107. Kalandidi A, Trichopoulos D, Hatzakis A, Tzannes S, 
Saracci R. Passive smoking and chronic obstructive pulmonary disease. Lancet 1987; ii: 1325-1326.

108. Dayal HH, Khuder S, Sharrar R, Trieff N. Passive smoking in obstructive respiratory diseases in an industrialized urban population. Environ Res 1994; 65: 161-171.

109. Sandler DP, Comstock GW, Helsing KJ, Shore DL. Deaths from all causes in non-smokers who lived with smokers. Am J Public Health 1989; 79: 163-167.

110. Robbins AS, Abbey DE, Lebowitz MD. Passive smoking and chronic respiratory symptoms in nonsmoking adults. Int $J$ Epidemiol 1993; 22: 809-817.

111. Berglund DJ, Abbey DE, Lebowitz MD, Knutsen SF, McDonnell WF. Respiratory symptoms and pulmonary function in an elderly nonsmoking population. Chest 1999; 115: 49-59.

112. Wright JL, Lawson LM, Pare PD, Kennedy S, Wiggs B, Hogg JC. The detection of small airways disease. Am Rev Respir Dis 1984; 129: 989-994.

113. Thurlbeck WM. Pathophysiology of chronic obstructive pulmonary disease. Clin Chest Med 1990; 11: 389 403.

114. Pauwels RA, Löfdahl C-G, Pride NB, Postma DS, Laitinen LA, Ohlsson SV. European Respiratory Society study on chronic obstructive pulmonary disease (EUROSCOP): hypothesis and design. Eur Respir J 1992; 5: 1254-1261.

115. Strachan DP, Cook DG. Parental smoking and lower respiratory illness in infancy and early childhood. Thorax 1997; 52: 905-914.

116. Nuorti JP, Butler JC, Farley MM, et al. Cigarette smoking and invasive pneumococcal disease. $N$ Engl $J$ Med 2000; 342: 681-689.

117. Green GM, Carolin D. The depressant effect of cigarette smoke on the in vitro antibacterial activity of alveolar macrophages. $N$ Engl J Med 1967; 276: 421-427.

118. Wanner A. State of the art: Clinical aspects of mucociliary transport. Am Rev Respir Dis 1977; 116: 73-125.

119. Fainstain V, Musher D. Bacterial adherence to pharyngeal cells in smokers, nonsmokers, and chronic bronchitis. Infect Immun 1979; 26: 178-182.

120. Dye JA, Adler KB. Effects of cigarette smoke on epithelial cells of the respiratory tract. Thorax 1994; 49: 825-834.

121. Law MR, Morris JK, Wald NJ. Environmental tobacco smoke exposure and ischaemic heart disease: an evaluation of the evidence. BMJ 1997; 315: $973-$ 980.

122. Thun M, Henley J, Apicella L. Epidemiologic studies of fatal and nonfatal cardiovascular disease and ETS exposure from spousal smoking. Environ Health Perspect 1999; 107: Suppl. 6, 841-846.

123. Steenland K. Risk assessment for heart disease and workplace ETS exposure among nonsmokers. Environ Health Perspect 1999; 107: Suppl. 6, 859-863.

124. Kawachi I, Colditz GA. Workplace exposure to passive smoking and risk of cardiovascular disease: Summary of epidemiologic studies. Environ Health Perspect 1999; 107: Suppl. 6, 847-851.

125. Wells AJ. An estimate of adult mortality in the United States from passive smoking: a response to criticism. Environ Int 1991; 17: 382-385.

126. Howard G, Thun MJ. Why is environmental tobacco smoke more strongly associated with coronary heart disease than expected? A review of potential biases and experimental data. Environ Health Perspect 1999; 107: Suppl. 6, 853-858.

127. Glanz SA, Parmley WW. Passive smoking and heart disease. Epidemiology, physiology, and biochemistry. Circulation 1991; 83: 1-12.

128. Taylor AE, Johnson DC, Kazemi H. Environmental tobacco smoke and cardiovascular disease. A position paper from the Council on Cardiopulmonary and Critical Care, American Heart Association. Circulation 1992; 86: 699-702.

129. Shinton R, Beevers G. Meta-analysis of relation between cigarette smoking and stroke. BMJ 1989; 298: 789-794.

130. Donnan GA, Adena MA, O'Malley HM, McNeil JJ, Doyle AE, Neill GC. Smoking as a risk factor for cerebral ischaemia. Lancet: 1989: 643-647.

131. Bonita R, Duncan J, Truelsen T, Jackson RT, Beaglehole R. Passive smoking as well as active smoking increases the risk of acute stroke. Tob Control 1999; 8: 156-160.

132. Trinder PM, Croft PR, Lewis M. Social class, smoking and the severity of respiratory symptoms in the general population. $J$ Epidemiol Community Health 2000; 54: 340-343.

133. Eisner MD, Smith AK, Blanc PD. Bartenders' respiratory health after establishment of smoke-free bars and taverns. JAMA 1998; 280: 1909-1914.

134. Dales RE, Kerr PE, Schweitzer I, Reesor K, Gougeon L, Dickinson G. Asthma management preceding an emergency department visit. Arch Intern Med 1992; 152: 2041-2044.

135. Abramson MJ, Kutin JJ, Rosier MJ, Bowes G. Morbidity, medication and trigger factors in a community sample of adults with asthma. Med J Aust 1995; 162: 76-81.

136. Tarlo SM, Broder I, Corey P, et al. A case-control study of the role of cold symptoms and other historical triggering factors in asthma exacerbations. Can Respir $J$ 2000; 7: 42-48.

137. Ostro BD, Lipsett MJ, Mann JK, Wiener MB, Selner J. Indoor air pollution and asthma. Results from a panel study. Am J Respir Crit Care Med 1994; 149: 1400-1406.

138. Jindal SK, Gupta D, Singh A. Indices of morbidity and control of asthma in adult patients exposed to environmental tobacco smoke. Chest 1994; 106: 746749 .

139. Sippel JM, Pedula KL, Vollmer WM, Buist AS, Osborne ML. Associations of smoking with hospitalbased care and quality of life in patients with obstructive airway disease. Chest 1999; 115: 691-696.

140. Jindal SK, Jha LK, Gupta D. Bronchial hyperresponsiveness of women with asthma exposed to environmental tobacco smoke. Indian J Chest Dis Allied Sci 1999; 41: 75-82.

141. Blanc PD, Ellbjär S, Janson C, et al. Asthma-related work disability in Sweden. The impact of workplace exposures. Am J Respir Crit Care Med 1999; 160: 2028-2033.

142. Ostro BD. Estimating the risks of smoking, air pollution, and passive smoke on acute respiratory conditions. Risk Anal 1989; 9: 189-196.

143. Mannino DM, Siegel M, Rose D, Nkuchia J, Etzel R. Environmental tobacco smoke exposure in the home and worksite and health effects in adults: results from the 1991 National Health Interview Survey. Tob Control 1997; 6: 296-305. 